\title{
Effect of replacing fish meal by full fat soybean meal on growth performance, feed utilization and gastrointestinal enzymes in diets for African catfish Clarias gariepinus
}

\author{
A. A. Abdel-Warith ${ }^{a, b *}$ (D), E. M. Younis ${ }^{a}$, N. A. Al-Asgah ${ }^{a}$ and S. Mahboob ${ }^{a}$ \\ ${ }^{a}$ Department of Zoology, College of Science, King Saud University, Riyadh, Saudi Arabia \\ ${ }^{b}$ Department of Animal Production, Faculty of Agriculture, Al-Azhar University, Nasr City, Cairo, Egypt \\ *e-mail: aaabdelwarith@yahoo.com
}

Received: October 6, 2018 - Accepted: March 14, 2019 - Distributed: August 31, 2020

(With 1 figure)

\begin{abstract}
Study aimed to evaluate the effect of replacing fish meal with different levels of full fat soybean meal (FFSBM) on growth and digestive enzyme activities in the stomach, Liver and intestine for Clarias gariepinus. Four diets

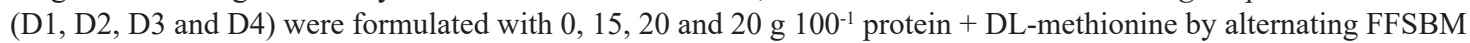
with fish meal. The growth of $C$. gariepinus was found to be significantly decreased when FFSBM replacement increased. Final body weight was $89.69,79.70,70.82$ and $68.29 \mathrm{~g}$ for fish fed on D1, D2, D3 and D4, respectively, with significant differences between treatments. Specific growth rate (SGR) ranged between 3.11 to $2.78 \%$. Proteolytic activity was higher only with alkaline $\mathrm{pHs}$, whereas only very low activity was shown with acidic. Results of liver showed approximately similar results at acid and alkaline. In contrast, higher proteolytic activity in the stomach was observed at acid pHs 3.0 and $4.0 \mu \mathrm{g}$ tyrosine $\mathrm{e}^{-1}$ minute $^{-1} \mathrm{mg}^{-1}$ protein) whereas lower values were observed at neutral $\mathrm{pH} 7.0 \mathrm{~g}$ tyrosine $\mathrm{e}^{-1}$ minute $^{-1} \mathrm{mg}^{-1}$ protein for catfish fed on the experimental diets. Moreover, trypsin activity was higher for the stomach, followed by the intestine and liver. However, higher amount of amylase observed in the liver than intestine and stomach.
\end{abstract}

Keywords: hepato-pancreas, amino acids, enzyme activities.

\section{Efeito da substituição de farinha de peixe por farelo de soja integral no desempenho de crescimento, utilização de ração e enzimas gastrointestinais em dietas para bagre africano Clarias gariepinus}

\begin{abstract}
Resumo
Objetivou-se avaliar o efeito da substituição da farinha de peixe por diferentes níveis de farelo de soja integral (FSI) sobre o crescimento e atividades de enzimas digestivas no estômago, fígado e intestino de Clarias gariepinus. Quatro

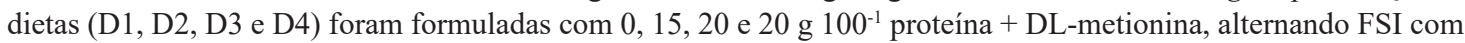
farinha de peixe. O crescimento de C. gariepinus foi significativamente reduzido quando aumentou a substituição de farinha de peixe por FSI . O peso corporal final foi de 89,69, 79,70, 70,82 e 68,29 g para peixes alimentados com D1, D2, D3 e D4, respectivamente, com diferenças significativas entre os tratamentos. Taxa de crescimento específico (TCE) variou entre 3,11 a 2,78\%. A atividade proteolítica foi maior apenas com pHs alcalinos, enquanto que atividades muito baixas foram somente mostradas com ácido. Os resultados no fígado mostraram valores aproximadamente semelhantes tanto em meio ácido quanto alcalino. Em contraste, observou-se maior atividade proteolítica no estômago em pH ácido (3,0 e 4,0 $\mathrm{g}_{\text {de tirosina }}{ }^{-1}$ minuto $^{-1} \mathrm{mg}^{-1}$ de proteína), ao passo que valores mais baixos foram observados em $\mathrm{pH}$ neutro ( 7,0 g de tirosina ${ }^{-1}$ minuto $^{-1} \mathrm{mg}^{-1}$ de proteína) para os bagres que se alimentaram com as dietas experimentais. Além disso, a atividade da tripsina foi maior para o estômago, seguida pelo intestino e pelo fígado. No entanto, observou-se maior quantidade de amilase no fígado,intestino e estômago.
\end{abstract}

Palavras-chave: hepatopâncreas, aminoácidos, atividades enzimáticas.

\section{Introduction}

Clarias gariepinus is an important species in fish culture sector related to its fertilization, high growth rate, tolerate of high stocking density, resistance to the common diseases and can able to accept a wide different of feed (Huisman and Richter, 1987). Many investigations have been conducted to evaluate the appropriateness of the 
plant and animal feedstuffs as substitutes for fishmeal in the diets of African catfish. Conventionally, fish meal has been considered to be the major source of protein because of its high contents of essential nutrients, balanced in amino acid profile, good growth performances and the fact that it is acceptable for most aquatic animals (Sun, et al., 2015). The problem, however, is that the protein source represents the highest cost element in feed for aquaculture and there is therefore an incentive to seek cheaper alternatives. Furthermore, the development of alternative protein sources, including plant proteins, means that fish meal can at least be partially substituted with more economical products (Francis, et al., 2001), like meal of poultry by product (Abdel-Warith, et al., 2001; Fagbenro and Davies, 2001; Goda, et al., 2007), waste of shrimp head (Nwanna et al., 2004) soybean meal (Imorou Toko, et al., 2008), rice husks meal (Zaid and Ganiyat, 2009), and grasshopper meal (Alegbeleye et al., 2012; Olaleye, 2015). Some investigations have been reported that partially substitute fish meal with soybean meal effects the performance of a few fish species, such as for Japanese seabass Lateolabrax japonicus (Zhang, et al., 2014), juvenile tench Tinca tinca L. (Garcia, et al., 2015), gilthead sea bream Sparus aurata L. (Kokou, et al., 2012), rainbow trout Oncorhynchus mykiss (Harlioğlu, 2011) and Nile tilapia Oreochromis niloticus (Abdel-Warith et al., 2013). Some Anti-nutritional factors ANFs suppress the activities of specific enzymes, such as proteinase and amylase; also, many protein components, such as haemagglutinins and lectins, can react in specific ways with certain carbohydrates (Hendricks, 2002). Protease enzymes such as trypsin and chymotrypsin are very important for the digestibility operations in digestive system of fish. These digestive enzymes, like others, are active into the proximal intestine. The hydrolysis of protein intake from the diets which occurs by these enzymes that active in the proximal intestine, serve to break down the protein to simple molecules that can then be absorbed throughout the intestine and used in the metabolic process (Lovatto et al., 2017). While some studies have focused their attention on the influence of different substitute plant proteins on fish growth and feed utilization, few have looked at how diet changes the activities of digestive enzymes) Xu et al. (2012) and Zhao et al. (2016).

This study aimed to investigate the potential use of partially substitution of fishmeal by full fat soybean meal in diets for the $C$. gariepinus by examine the subsequent effects on growth performance, feed utilization and the digestive enzyme activities in the stomach, hepato-pancreas and intestine, given that these are still poorly understood, especially in respect to $C$. gariepinus.

\section{Material and Methods}

\subsection{Experimental fish}

A total of 160 C. gariepinus with average weight $7.82 \pm 2.02 \mathrm{~g})$ were distributed into eight fiberglass tanks containing $100 \mathrm{~L}$ of water, and were suspended over a 1000 litre bio-filter. Water entered each tank via a spray bar after filtration and an aerator was placed in the center of the tank. Partial water changes amounted approximately $20 \%$ of the systems volume per week. Filters of the systems were cleaned daily to avoid the buildup of nitrate levels in the water. 20 fish have been distributed in each tank with replicate. Treatments of water temperature were monitored at $28 \pm 1^{\circ} \mathrm{C}$ by controlled heaters (Atman, AT-300W), the values of $\mathrm{pH}$ maintained at 7.1-8.0, ammonia (NH3) (0.07-0.20 $\left.\mathrm{mg} \mathrm{L}^{-1}\right)$, nitrite (NO2) (0.15-0.35 $\left.\mathrm{mg} \mathrm{L}^{-1}\right)$, nitrate (NO3) (4.35-5.77 $\left.\mathrm{mg} \mathrm{L}^{-1}\right)$ and dissolved oxygen (5.3-6.7 $\mathrm{mg} \mathrm{L}^{-1}$ ) were all monitored twice a week to ensure that they remained at acceptable levels. Other twenty fish were euthanized using buffered MS222 (50 mg/l) then kept frozen at $-20^{\circ} \mathrm{C}$ to estimate the initial chemical analysis of carcass composition. At the end of the experiment, five fish of each treatment were dissected and sample of stomach, liver and intestine were removed and kept frozen at $-80^{\circ} \mathrm{C}$ for enzymes assays, other five fish of each group were used for final carcass composition.

\subsection{Diet formulation}

Experimental diets were prepared in various levels of full fat soybean (FFSBM) substituted by fishmeal. Table 1 shows the formulation and chemical analysis of experimental diets, and Table 2 observed the diets contents of essential amino acids expressed as percentage of protein. Experimental diets were prepared to replace the fishmeal protein with full-fat soybean with ratio

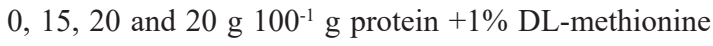
for D1, 2, 3 and 4, respectively.

\subsection{Experimental procedure}

Weight of fish have been done every two weeks and fed $3.5 \%$ by hand twice a day of their body weight six days a week for the first half of the period ( 6 weeks), reduced to $3 \%$ for the second half ( 6 weeks), giving an average of $3.25 \%$. The experiment was held for 12 -week and the feed intake was regulated according to the increase of biomass. Five fish from each group were collected at the end of the experimental period, then dissected and sample of stomach, liver and intestine were removed and kept frozen at $-80^{\circ} \mathrm{C}$ for enzymes assays, other five fish from each treatment were euthanized and frozen at $-20{ }^{\circ} \mathrm{C}$ to determine final chemical composition.

\subsection{Proximate composition}

Chemical analyses of fish carcass and diets for moisture, lipid, protein, and ash were estimated using AOAC (1995) methods and gross energy were calculated according to Hepher et al. (1983).

\subsection{Estimation of growth and nutrients efficiency}

Specific growth rate $($ SGR \%) $=$

$[\operatorname{Ln} \operatorname{FBW}(\mathrm{g})-\operatorname{Ln} \operatorname{IBW}(\mathrm{g})] /$ feeding days $\times 100$

Whereas: FBW final body weight, IBW initial body weight 
Table 1. Composition and proximate analysis of the control and test diets (g/100 g dry weight) fed to Clarias gariepinus.

\begin{tabular}{|c|c|c|c|c|}
\hline \multicolumn{5}{|c|}{ Experimental diets } \\
\hline Ingredients & $\begin{array}{c}\mathrm{D1}(\mathbf{0} \mathrm{g} / 100 \mathrm{~g} \\
\text { protein })\end{array}$ & $\begin{array}{c}\mathrm{D} 2(15 \mathrm{~g} / 100 \mathrm{~g} \\
\text { protein })\end{array}$ & $\begin{array}{c}\mathrm{D3}(20 \mathrm{~g} / 100 \mathrm{~g} \\
\text { protein })\end{array}$ & $\begin{array}{c}\text { D4(20 g/100 g } \\
\text { Protein }+ \text { AAs })\end{array}$ \\
\hline Fish meal $^{1}$ & 43.00 & 23.00 & 16.00 & 16.00 \\
\hline Full-fat soybean meal ${ }^{2}$ & & 41.00 & 57.00 & 57.00 \\
\hline Wheat meal ${ }^{3}$ & 32.00 & 20.00 & 17.50 & 16.50 \\
\hline Corn oil ${ }^{4}$ & 8.77 & 2.30 & & \\
\hline Cod liver oil ${ }^{5}$ & 0.70 & 2.90 & 2.50 & 2.50 \\
\hline Vitamin premix ${ }^{6}$ & 2.00 & 2.00 & 2.00 & 2.00 \\
\hline Mineral premix ${ }^{7}$ & 1.00 & 1.00 & 1.00 & 1.00 \\
\hline DL-Methionine & & & & 1.00 \\
\hline Binder $^{8}$ & 2.00 & 2.00 & 2.00 & 2.00 \\
\hline$\propto-$ Cellulose ${ }^{9}$ & 10.03 & 4.80 & & \\
\hline \multicolumn{5}{|c|}{ Proximate composition ( $\%$ as fed) } \\
\hline Moisture & 4.23 & 3.25 & 3.85 & 4.05 \\
\hline Protein & 36.55 & 35.73 & 35.51 & 36.42 \\
\hline Lipid & 14.33 & 15.18 & 14.79 & 14.56 \\
\hline Ash & 7.41 & 7.29 & 8.28 & 8.22 \\
\hline Gross energy $\left(\mathrm{MJkg}^{-1}\right)^{10}$ & 20.78 & 20.97 & 20.77 & 20.37 \\
\hline
\end{tabular}

${ }^{1}$ Fish meal LT94, Trouw Aquaculture (Nutreco company); ${ }^{2}$ Full fat soybean, Central Soya Michigan, USA; ${ }^{3}$ Wheat meal, Kalpro $\mathrm{S}^{\mathrm{TM}}$. Orsan, Paris, France; ${ }^{4}$ Mazola- pure corn oil; ${ }^{5}$ Fish oil- seven pure cod liver oil; ${ }^{6}$ Vitamin premix, Trouw Aquaculture (Nutreco company); ${ }^{7}$ Mineral premix, Trouw Aquaculture (Nutreco company); ${ }^{8}$ Carboxymethyl Cellulose (CMC); ${ }^{9}$ Sigma Chemical Co., Poole, Dorset; ${ }^{10}$ Gross energy (GE) was calculated according to Hepher et al. (1983) using the equivalent factors of $5.65,9.45$ and $4.2 ; \mathrm{kcal} / \mathrm{g}$ for CP, EE, and NFE, respectively

Table 2. The amino acid composition of the test diets is expressed as a percent of protein fed to Clarias gariepinus and their requirements.

\begin{tabular}{lccccc}
\hline \multicolumn{1}{c}{ Amino acids } & \multicolumn{3}{c}{ Experimental diets } & C. gariepinus \\
Req*
\end{tabular}

*Amino acid requirement according to NRC (1993); ND (not detected).

Feed conversion ratio $(\mathrm{FCR})=\mathrm{FI}(\mathrm{g}) / \mathrm{BWG}(\mathrm{g})$

Whereas: FI feed intake and BWG body weight gain

Protein efficiency Ratio(PER) $=$ BWG $(g) /$ PI protein intake $(g)$

Whereas: BWG body weight gain and PI protein intake Apparent net protein utilization $($ ANPU \%) $=$ $(\%$ FBP $\times$ FBW $)-(\%$ IBP $\times$ IBW $) /$ TPI $(\mathrm{g}) \times 100$

Whereas: FBP final body protein, FBW final body weight, IBP initial body protein, IBP initial body weight and TPI total protein intake

\subsection{Determination of amino acids}

The amino acid contents of the diets were determined following acid hydrolysis method of McCullagh et al. (2006). Amino acids were assayed using a Kontron Chromakon 500 automatic amino acid analyzer [column $250 \times 4.6 \mathrm{~mm}$, cation ion-exchange resin material (AS70)] and the procedures were done as described in our previous studies Abdel-Warith et al. (2014). Table 2 showed the amino acids composition expressed as $\%$ of protein in the diets.

\subsection{Determination of enzymes}

Proteolytic activity of enzymes were expressed as the amount of tyrosine $(\mu \mathrm{g})$ digested by $100 \mu \mathrm{l}$ of enzyme 
solution /minute/mg protein at acid, natural and alkaline $\mathrm{pHs}$ at $37^{\circ} \mathrm{C}$ and determined using the casein hydrolysis according to the method of Kunitz (1947) as modified by Walter (1984). Trypsin activity was expressed as the amount of tyrosine $(\mu \mathrm{g})$ liberated by $0.5 \mathrm{ml}$ of enzyme extract per minutes $/ \mathrm{mg}$ protein at $37^{\circ} \mathrm{C}$ and measured in the test tubes using benzoyl-Arg- $p$-nitroanilide (BAPNA) as a substrate according to Erlanger et al. (1961). Amylase activity were expressed as the amount of maltose liberated by $50 \mu \mathrm{l}$ of enzyme extract $/$ minute $/ \mathrm{ml}$ at $37{ }^{\circ} \mathrm{C}$ then assayed by the starch hydrolysis method According to Tietz (1970). However, the lipase activity was expressed as the amount of fatty acids neutralized by $0.05 \mathrm{NaOH}$ liberated by $1 \mathrm{ml}$ enzyme solution minute at $37^{\circ} \mathrm{C}$, and determined by the aid of a Sigma diagnostic test-kit.

\subsection{Statistical analysis}

Data were analyzed using a one-way analysis of variance (ANOVA) technique. The means were separated by Fisher's LSD test and compared using Duncan's Multiple Range Test, as described by Snedecor and Cochran (1989). The significant differences level was defined at $\mathrm{P}<0.05$.

\section{Results}

\subsection{Growth performance}

Results of growth performance and feed utilization for the $C$. gariepinus fed the experimental diets are displayed in Table 3. Growth performance (mean final weight, weight gain and specific growth rate (SGR) Equation 1 decreased significantly as increasing proportions of FFSBM were included in the diets (from D2 to D4). Amino acid supplementation had no effect on the parameters when compared with an unsupplemented diet3. The results obtained for final weight were 89.69, 79.70, 70.82 and $68.29 \mathrm{~g}$ for catfish fed the experimental diets, with significant differences between treatments (Table 3 ). The results for SGR were 3.11, 2.98, 2.82 and 2.78 for fish fed D1, D2, D3 and D4 respectively.

\subsection{Feed consumption and feed utilization}

Clarias gariepinus well accepted to the control diet whereas, the palatability for other test diets containing partial replacement with FFSBM were decline. Average of feed intake ranged between 0.85 and $0.72 \mathrm{~g} \mathrm{fish}^{-1} \mathrm{day}^{-1}$. The presence of FFSBM in the diet had a noticeable effect on feed intake (Table 3). The results of feed intake showed significant difference $(\mathrm{P}<0.05)$ between fish fed $\mathrm{D} 1$ and D2 when compared with D3 and D4 which containing high levels of FFSBM even with adding methionine to D4. The results obtained of Feed Conversion Ratio (FCR) Equation 2 showed significant differences $(\mathrm{P}<0.05)$ among fish fed on control diet (0.82) and the other groups fed on diets containing different levels FFSBM especially D4, However, D1, D2 and D3 are presented similar FCR, also, in the same way of D2, D3 and D4.with FCRs of 0.87 for D2, 0.91 for D3 and 0.93 for D4 (including amino acid supplementation) respectively, The protein efficiency ratio (PER) Equation 3 was also showed significant differences $(\mathrm{P}<0.05)$ between D1 and D4; However, D2, D3 and D4 are presented no significant differences between treatments. Superior PER (3.36) was obtained for fish fed control diet while fish fed different inclusion levels of FFSBM observed PERs of 3.24, 3.12 and 2.97. Apparent net protein utilization (ANPU \%) Equation 4 also supported this trend with significant differences $(\mathrm{P}<0.05)$ between the control and D4. however, no significant differences between D2, D3, and D4. The ANPU for catfish fed a control diet was $54.48 \%$, whereas the lowest value was observed for fish

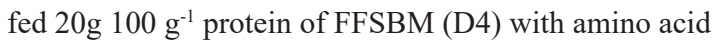
supplementation, at $48.6 \%$ (Table 3 ).

\subsection{Fish body composition}

Table 4 shows the chemical of carcass composition for fish fed the experimental diets. Carcass composition of final body of fish showed slightly significant differences as a result of experimental diet. There were few differences in the moisture content, whereas, the protein and lipid content and ash content showed only slight differences $(P>0.05)$ between treatments Table 4

\subsection{Enzyme activities}

\subsubsection{Proteolytic activity}

The total activity of proteolytic enzymes used the (sum of pHs 1.5, 3, 4, 7, 8.5, 9, and 10) showed higher activity in the intestine than the activity of this enzyme in the stomach and liver which ranged

Table 3. Weight increase, feed consumption, nutritive utilization of feed and protein for Clarias gariepinus $(\mathrm{mean} \pm \mathrm{SD})$.

\begin{tabular}{|c|c|c|c|c|}
\hline & D1 & D2 & D3 & D4 \\
\hline Mean initial weight $(\mathrm{g})$ & $7.85 \pm 2.31$ & $7.83 \pm 1.76$ & $7.88 \pm 1.99$ & $7.80 \pm 2.02$ \\
\hline Mean final weight (g) & $88.69 \pm 4.27^{\mathrm{b}}$ & $79.7 \pm 1.09^{\mathrm{b}}$ & $70.82 \pm 1.42^{\mathrm{a}}$ & $68.29 \pm 3.54^{\mathrm{a}}$ \\
\hline Mean weight gain $(\mathrm{g})$ & $80.86 \pm 4.25^{b}$ & $71.87 \pm 1.03^{\mathrm{b}}$ & $62.94 \pm 1.34^{\mathrm{a}}$ & $60.49 \pm 3.54^{\mathrm{a}}$ \\
\hline Mean daily feed Intake $\left(g_{\text {fish }}^{-1}\right.$ d) & $0.85 \pm 0.01^{\mathrm{b}}$ & $0.80 \pm 0.01^{\mathrm{b}}$ & $0.73 \pm 0.03^{\mathrm{a}}$ & $0.72 \pm 0.01^{\mathrm{a}}$ \\
\hline SGR $(\%)^{1}$ & $3.11 \pm 0.06^{\mathrm{c}}$ & $2.98 \pm 0.01^{\mathrm{b}}$ & $2.82 \pm 0.01^{\mathrm{a}}$ & $2.78 \pm 0.07^{\mathrm{a}}$ \\
\hline $\mathrm{FCR}^{2}$ & $0.82 \pm 0.05^{\mathrm{a}}$ & $0.87 \pm 0.02^{\mathrm{ab}}$ & $0.91 \pm 0.02^{\mathrm{ab}}$ & $0.93 \pm 0.06^{\mathrm{b}}$ \\
\hline $\mathrm{PER}^{3}$ & $3.36 \pm 0.13^{b}$ & $3.24 \pm 0.09^{\mathrm{ab}}$ & $3.12 \pm 0.07^{\mathrm{ab}}$ & $2.97 \pm 0.18^{\mathrm{a}}$ \\
\hline ANPU $(\%)^{4}$ & $54.48 \pm 1.01^{\mathrm{b}}$ & $51.88 \pm 1.53^{\mathrm{ab}}$ & $52.63 \pm 1.23^{\mathrm{ab}}$ & $48.60 \pm 2.89^{\mathrm{a}}$ \\
\hline
\end{tabular}

Values in the same row with different letters indicate significant difference $(\mathrm{P}<0.05) ;{ }^{1} \mathrm{SGR}$ : [Ln final body weight $(\mathrm{g})$ - $\mathrm{Ln}$ initial body weight $(\mathrm{g})] /$ feeding days $\times 100$; ${ }^{2} \mathrm{FCR}$ : feed intake $(\mathrm{g}) /$ body weight gain $(\mathrm{g}) ;{ }^{3}$ PER: body weight gain $(\mathrm{g}) /$ protein intake $(\mathrm{g})$; ${ }^{4}$ ANPU $(\%)=(\%$ final body protein $\times$ final body weight $)-(\%$ initial body protein $\times$ initial body weight $) /$ total protein ntake $(\mathrm{g}) \times 100$. 
between 5.68 to $2.98 \mu \mathrm{g}$ tyrosine $\mathrm{m}^{-1}$ minute $^{-1} \mathrm{mg}^{-1}$ protein. The mean of the activities of proteolytic between $C$. gariepinus fed on all diets did not observe any significant difference $(p>0.05)$ in the intestine. However, the results obtained of proteolytic activities in the stomach showed a significant differences $(\mathrm{P}<0.05)$ between fish fed control diets when compared to other fish fed D2, D3 and D4 that containing high amount of FFSBM (Table 5). Proteolytic activity in the liver was less than the activity of the stomach, however, and also the mean of proteolytic activity of sum of pHs $\mu \mathrm{g}$ tyrosine $\mathrm{m}^{-1}$ minute $^{-1} \mathrm{mg}^{-1}$ protein showed a decreased when replacement FFSBM increased for all organs for $C$. gariepinus fed the experimental diets.

Proteolytic Activities of enzyme for the intestine were higher with alkaline $\mathrm{pHs}$, whereas only very low amounts of activity were observed with acidic pHs (Figure 1). For liver, the proteolytic activity recorded showed similar results at acid and alkaline pHs. In contrary, the proteolytic activity in the stomach was higher at acid pHs (3.0 and $4.0 \mu \mathrm{g}$ tyrosine $\mathrm{e}^{-1}$ minute $^{-1} \mathrm{mg}^{-1}$ protein) whereas lower amounts were recorded at neutral $\mathrm{pH} 7.0$ (Figure 1) for catfish fed experimental diets.

\subsubsection{Trypsin activity}

Trypsin activities were also higher in the stomach, followed by intestine and liver. While there were no significant differences $(p>0.05)$ between the treatments in respect to the liver and stomach, there was significantly higher trypsin activity in the intestines 2.75 of fish fed the control basic diet (Table 5) when compared with C. gariepinus fed D2, D3 and D4 which resulted 2.31, 2.07 and 1.71 respectively.

\subsubsection{Amylase activity}

Amylase activity showed the highest values in the liver compared to the intestine and stomach (Table 5). Higher amount of amylase was observed in the hepatic tissue of catfish fed the control diet, $4.49 \mu \mathrm{g}$ maltose $\mathrm{e}^{-1}$ minute $^{-1} \mathrm{ml}^{-1}$ followed by that of C. gariepinus fed on D2 (2.94). C. gariepinus fed diets 3 and 4 showed lower values of amylase activity. Only a little value of amylase activities were revealed in the stomach and intestine Table 5.

Table 4. Body composition of Clarias gariepinus fed graded levels of FFSB ( $\mathrm{g} 100^{-1} \mathrm{~g}$ wet weight) of whole fish experiment diets $($ mean $\pm \mathrm{SD})$.

\begin{tabular}{cccccc}
\hline & Initial fish & D1 & D2 & D3 & D4 \\
\hline Moisture & 76.45 & $72.24 \pm 1.26^{\mathrm{a}}$ & $72.71 \pm 1.81^{\mathrm{a}}$ & $72.97 \pm 1.19^{\mathrm{a}}$ & $73.81 \pm 1.39^{\mathrm{a}}$ \\
Protein & 12.01 & $16.01 \pm 0.27^{\mathrm{ab}}$ & $15.82 \pm 0.48^{\mathrm{a}}$ & $16.55 \pm 0.55^{\mathrm{b}}$ & $16.11 \pm 0.49^{\mathrm{ab}}$ \\
Lipid & 7.40 & $9.75 \pm 1.05^{\mathrm{bc}}$ & $10.24 \pm 0.96^{\mathrm{c}}$ & $9.24 \pm 0.55^{\mathrm{b}}$ & $7.99 \pm 0.33^{\mathrm{a}}$ \\
Ash & 2.46 & $3.27 \pm 0.10^{\mathrm{b}}$ & $2.96 \pm 0.15^{\mathrm{a}}$ & $3.04 \pm 0.19^{\mathrm{a}}$ & $2.96 \pm 0.10^{\mathrm{a}}$ \\
\hline
\end{tabular}

Values in the same row with different letters indicate significant difference $(\mathrm{P}<0.05)$.

Table 5. Total proteolytic, trypsin, amylase and lipase activities in intestine, liver and stomach of Clarias gariepinus fed control and test diets determined at $37^{\circ} \mathrm{C}($ mean $\pm \mathrm{SD})$.

\begin{tabular}{|c|c|c|c|c|c|}
\hline & $\begin{array}{l}\text { Proteolytic } \\
\text { activity } \\
\text { (mean) }\end{array}$ & $\begin{array}{c}\text { Proteolytic } \\
\text { Sum of pHs* } \\
\text { ( } \mu \text { g tyrosine/ } \\
\text { min }^{-1} \mathrm{mg}^{-1} \text { protein) }\end{array}$ & $\begin{array}{c}\text { Trypsin activity } \\
\text { ( } \mu \mathrm{g} \text { tyrosine/ } \\
\mathrm{min}^{-1} \mathrm{mg}^{-1} \text { protein) }\end{array}$ & $\begin{array}{c}\text { Amylase activity } \\
\text { ( } \mu \mathrm{g} \text { maltose/ } \\
\left.\mathrm{ml}^{-1} \mathrm{~min}^{-1}\right)\end{array}$ & $\begin{array}{c}\text { Lipase activity } \\
\text { (Sigma/Tietz/ } \\
\text { unit/L)/min } \text { ml }^{-1}\end{array}$ \\
\hline \multicolumn{6}{|c|}{ Intestine } \\
\hline D1 & $0.81 \pm 0.57^{\mathrm{a}}$ & 5.68 & $2.75 \pm 0.18^{b}$ & $0.96 \pm 0.37^{b}$ & $1.87 \pm 0.49^{\mathrm{b}}$ \\
\hline D2 & $0.47 \pm 0.25^{\mathrm{a}}$ & 3.26 & $2.39 \pm 0.66^{\mathrm{ab}}$ & $1.01 \pm 0.30^{\mathrm{b}}$ & $1.37 \pm 0.38^{\mathrm{ab}}$ \\
\hline D3 & $0.43 \pm 0.20^{\mathrm{a}}$ & 2.98 & $2.07 \pm 0.97^{\mathrm{ab}}$ & $0.67 \pm 0.19^{\mathrm{a}}$ & $1.14 \pm 0.25^{\mathrm{a}}$ \\
\hline D4 & $0.48 \pm 0.31^{\mathrm{a}}$ & 3.38 & $1.71 \pm 0.73^{\mathrm{a}}$ & $0.94 \pm 0.29^{b}$ & $1.07 \pm 0.18^{\mathrm{a}}$ \\
\hline \multicolumn{6}{|c|}{ Liver } \\
\hline D1 & $0.15 \pm 0.02^{\mathrm{a}}$ & 1.08 & $1.37 \pm 0.31^{\mathrm{a}}$ & $4.49 \pm 1.17^{\mathrm{c}}$ & $1.01 \pm 0.40^{\mathrm{a}}$ \\
\hline D2 & $0.22 \pm 0.03^{\mathrm{b}}$ & 1.54 & $1.42 \pm 0.39^{\mathrm{a}}$ & $2.94 \pm 0.98^{\mathrm{ab}}$ & $0.92 \pm 0.16^{\mathrm{a}}$ \\
\hline D3 & $0.20 \pm 0.03^{b}$ & 1.41 & $1.33 \pm 0.29^{\mathrm{a}}$ & $2.46 \pm 0.86^{\mathrm{a}}$ & $1.12 \pm 0.31^{\mathrm{a}}$ \\
\hline D4 & $0.14 \pm 0.01^{\mathrm{a}}$ & 0.95 & $1.05 \pm 0.65^{\mathrm{a}}$ & $3.66 \pm 0.63^{\mathrm{bc}}$ & $0.97 \pm 0.43^{a}$ \\
\hline \multicolumn{6}{|c|}{ Stomach } \\
\hline D1 & $0.54 \pm 0.17^{\mathrm{b}}$ & 3.79 & $3.09 \pm 0.79^{\mathrm{a}}$ & $0.76 \pm 0.18^{\mathrm{ab}}$ & $1.10 \pm 0.55^{\mathrm{a}}$ \\
\hline D2 & $0.29 \pm 0.24^{\mathrm{a}}$ & 2.03 & $2.77 \pm 0.66^{\mathrm{a}}$ & $0.82 \pm 0.18^{\mathrm{b}}$ & $1.18 \pm 0.57^{\mathrm{a}}$ \\
\hline D3 & $0.31 \pm 0.13^{\mathrm{a}}$ & 2.17 & $2.27 \pm 0.43^{\mathrm{a}}$ & $0.65 \pm 0.14^{\mathrm{a}}$ & $1.21 \pm 0.45^{\mathrm{a}}$ \\
\hline D4 & $0.20 \pm 0.09^{\mathrm{a}}$ & 1.40 & $2.29 \pm 0.46^{\mathrm{a}}$ & $0.69 \pm 0.10^{\mathrm{ab}}$ & $1.11 \pm 1.13^{\mathrm{a}}$ \\
\hline
\end{tabular}

*Total proteolytic activity was obtained as the sum of those determined at $\mathrm{pH} 1.5,3,4,7,8.5,9$, and 10; Values in the same column with different letters indicate significant difference $(\mathrm{P}<0.05)$. 


\subsubsection{Lipase activities}

In addition, lipase activities supported this trend, with a significant difference among the groups in the intestine but not in the stomach and liver (Table 5). Although, results of lipase activities in the intestine were 1.87, 1.37, 1.14 and 1.07 for fish fed D1, D2, D3 and D4 respectively with significant differences $(\mathrm{P}<0.05)$. between $\mathrm{D} 1$ and $\mathrm{D} 2$ when compared with D3 and D4 therefore, data also, showed no significant different $(p>0.05)$ among all groups fed diets containing FFSBM Table 5.

\section{Discussion}

The results obtained in this study show that plant ingredients used as a protein sources for example full fat soybean can be effective when replaced less than $50 \%$ of the fishmeal protein (LT94) in the diets for C. gariepinus. Catfish growth was slightly inferior with a diet containing about $15 \mathrm{~g} / 100 \mathrm{~g}$ protein $\mathrm{D} 2$ but highly significant inferior in catfish fed $20 \mathrm{~g} / 100 \mathrm{~g}$ protein and $20 \mathrm{~g} / 100 \mathrm{~g}$ of total protein of FFSBM with additional of DL-methionine compared with fishmeal as the only protein source. Also, catfish fed $20 \mathrm{~g} / 100 \mathrm{~g}$ of total protein of FFSBM with supplementation of DL-methionine did not improve their growth performance when compared to the unsupplemented diet. These results are in agreement with data obtained by Fagbenro and Davies (2001) who found that high nutritional value of soybean flour possesses used as a protein source in African catfish diets, particular partial substitution $(>50 \%)$ of the protein from fish meal source in the diet. They also showed that there was a decrease in growth, inferior in the utilization of protein efficiency.

The results in this study showed that FFSBM diets were

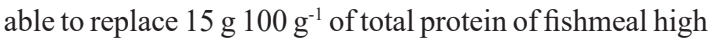
quality protein in C. gariepinus diets however, the growth and utilization of feed reduced with diets D3 and D4. Santigosa et al. (2008) reported that substitution of fish meal by plant ingredients as a protein source caused a decline in growth in other two fish species, rainbow trout Oncorhynchus mykiss and sea bream Sparus aurata. We argue that additional of amino acids may be inefficiently utilized by $C$. gariepinus this might be related to the presence of many anti-nutritional factors in plant ingredients that limit the utilization of dietary amino acids.

In addition, the palatability of FFSBM for catfish appeared to be less than has been found for tilapia (Abdel-Warith et al., 2013), as observed in daily feed intake records (Table 3), and certainly less than for fishmeal based diets for C. gariepinus. The results in this study were in general in accordance with data obtained for yellowtail (Seriola quinquertidiat) by Shimeno et al. (1993) when they also found reduced palatability in fish fed protein sources from plant replaced by fish meal. Another reason for decline the utilization of feed in the FFSBM diets is inferior in the digestibility of plant ingredients protein (Davies et al., 2011) which might be related to the high contents of anti-nutrition factors (ANFs), which inhibit the digestive enzymes.
Data in this study are in agreement with the results obtained by Luo et al. (2006) who demonstrated that diets containing more than $50 \%$ of solvent extracted cotton seed meal fed to Oncorhynchus mykiss had poorer growth performance since the diet contained less lysine than this fish needs. In the present study amino acid supplementation in D4 replacing $20 \mathrm{~g} / 100 \mathrm{~g}$ of total protein in the diets did not improved SGR Equation 1, FCR Equation 2, PER Equation 3, and ANPU Equation 4, for C. gariepinus when compared with the other diets. This might be because C. gariepinus cannot utilize the plant ingredients because catfish is a carnivorous species; this leads us to suggest that C. gariepinus can utilize diets containing up to $15 \mathrm{~g} / 100 \mathrm{~g}$ of total protein (about $41 \%$ of FFSBM) to observed that performance is less negatively affected at the lower level of supplementation than higher levels Shiau et al. (1990) reported that WG, FCR, PER and the digestibility of protein in hybrid tilapia $(O$. niloticus $\times O$. aureus $)$ can be improved by the substitution of up to $30 \%$ of the fishmeal in diets with defatted soybean and full-fat soybean. This study observed that the decrease of performance may be related to the high level of replacement plant materials protein leading to an imponderable of nutrients, particularly composition of protein. This may be due to an insufficient amino acid profile when FFSBM is supplemented to D2, D3 and D4. Full fat soybean has a certain amounts of both lysine and methionine, which affects the dietary contents of these amino acids, except for D4 (Table 2). ANPU values in the current study were not greatly affected except with methionine supplementation.

Protease Inhibitors especially in legumes are known to reduce the performance of growth in freshwater prawn Macrobrachium rosenbergii (Sriket et al., 2011). In the present study, only lower amount of proteolytic activity at acidic $\mathrm{pH}$ levels was found in the hepato-pancreas and intestine whilst, activity detected to be high in stomach (Figure 1) this related possibly to the fact that there are some intra-cellular enzymes which perform optimally at acidic $\mathrm{pH}$. Also, the results in the current research were in accordance with those of El-Beltagy et al. (2004) who illustrated that the highest activity of partially purified acidic protease had recorded at $\mathrm{pH} 2.5$ and then declined with rising of the $\mathrm{pH}$. In contrast, at alkaline $\mathrm{pHs}$, a higher amount of proteolytic activity was observed in both the intestine and hepato-pancreas. This agrees with data the obtained by Melo et al. (2012) who reported that the digestive tract of juvenile silver catfish showed higher activities of enzyme in the anterior section of the intestine at higher alkaline proteases. Similar results are reported in other species such as Gptosternum maculatum (Xiong et al., 2011).

Hidalgo et al. (1999) demonstrated that eels (Anguilla anguilla) had high proteolytic activity associated with a low gastrointestinal tract $\mathrm{pH}$ together with significant activities for proteolytic enzymes at higher gastrointestinal $\mathrm{pH}$ 's. Das and Tripathi (1991) reported that optimum activity of protease was found when $\mathrm{pH}$ ranged between 7.6 and 8.4 in grass carp Ctenpharyngodon idella fingerling and adult. 


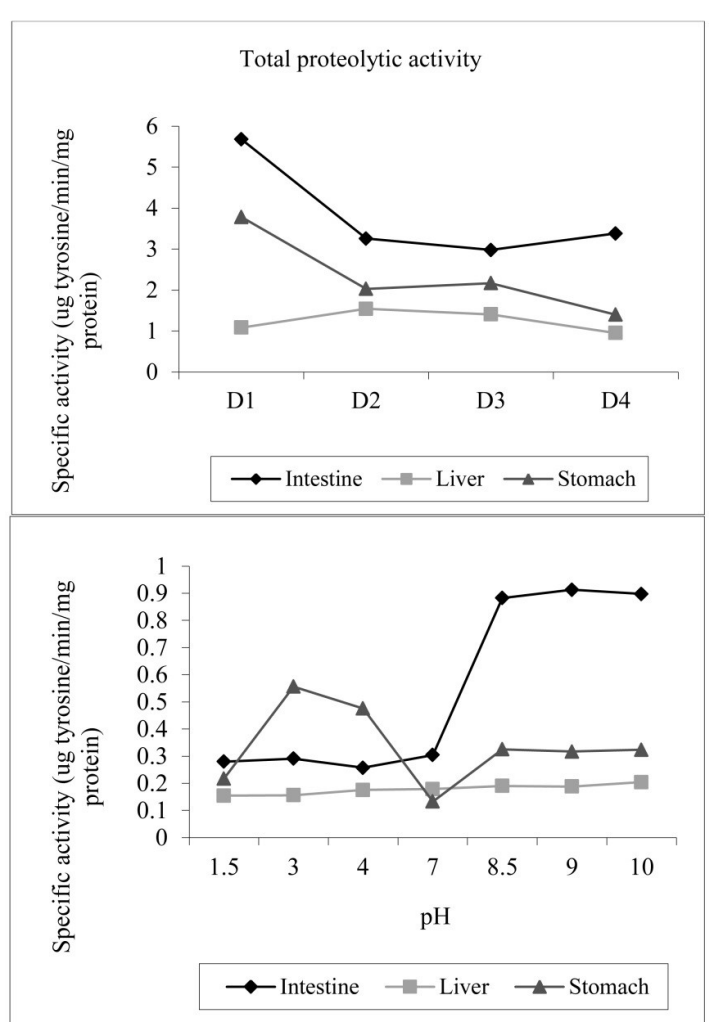

Figure 1. Total proteolytic activity (PA) in intestine, liver and stomach in Clarias gariepinus fed different levels of FFSBM (Top) is total proteolytic activity (PA) for control and test diets, (Bottom) is average PA affected by different $\mathrm{pHs}$ (mean $\pm \mathrm{SD}$ ).

In this experiment, however, the optimum proteolytic activity was recorded in different organs. I.e. in the catfish intestine optimum $\mathrm{pH}$ ranged between 8.5 to 10 Also, the catfish stomach showed optimum proteolytic activity at pH 3.0 and 4.0 however, Abdel-Warith et al. (2013) reported that the data obtained of tilapia showed optimum proteolytic activity in tilapia intestine was at $\mathrm{pH} 7.0-8.5$, whereas, in the stomach was at $\mathrm{pH} 1.5-3.0$, this gives an indicator that in thick-walled muscular stomachs, such as C. gariepinus, the $\mathrm{pH}$ is quite high at around 4 .

Lovatto et al. (2017) argued that higher trypsin activity in silver catfish (Rhamdia quelen) fed diets containing pumpkin seed meal represents the body's attempt to increase the digestibility of protein, that adverse in increased activities of the proteolytic. Alarcon et al. (2001) who found that the connection between the trypsin activities in the intestinal and the digestibility of protein in L. argentiventris and $L$. novemfasciatus, inhibitor activity of the enzyme appears to be offset by raising the secretion of enzymes proteolytic and increased protein absorption in distal parts of the intestine. In the contrary, the activities of trypsin were higher in Salmo salar fed pea protein concentrate (Penn et al., 2011). Song et al. (2014) also found that in Platichthys stellatus fed diets containing $15-70 \%$ of soybean protein hydrolysate replaced by fish meal showed higher trypsin activity.

Amylase activity in different organs (stomach, liver and intestine) also varied for C. gariepinus in the present study. The highest values were measured in the liver compared with the stomach and intestine. Fish fed high inclusion levels of FFSBM effected on the activities of amylase in the liver, with fish fed D4 (containing a high level of FFSBM with amino acid supplementation) showed higher values than those on FFSBM diets without AA supplementation. This indicated that the supplementation of amino acid improved enzyme activities. The lower value of amylase in the stomach, meanwhile, indicates that small amount of starch is digested before the food reaches the foregut. Al-Owafeir (1999) found that activity of $\alpha$-amylase was especially existing in Nile tilapia; this might be indicate that the tilapia is more ability to using and digesting carbohydrates than African catfish. Relatively few investigations have been undertaken of lipase activity in African catfish.

Lipase activity in this study was shown to be slightly higher in the intestine than in the liver and stomach. Tengjaroenkul et al. (2000) reported that activity of lipolytic enzymes absolutely exists in Nile tilapia $O$. niloticus, and occurs fundamentally in the cranial half of the intestinal in the digestive tract. While Melo et al. (2012) reported that lipase was stimulated by the lipid content in the diets.

Based on the results of this study we conclude that African catfish responded to diets of varying levels of FFSBM incorporation and grew favorably up to an inclusion level of about $41 \%$, of the original fishmeal component with less negatively affected at the lower level of supplementation than it is at the higher levels affected growth adversely, however, even with AAs supplementation, and also resulted in changes in the digestive enzyme activities. Anti-nutritional factors (ANF's) associated with FFSBM possibly caused a further depression in growth rate, feed utilization efficiency and also negative changes to several key enzyme activity levels associated with the gastrointestinal tract. Futures studies should consider how to improve the utilization of plant ingredients by adding some materials to the diets such as phosphorus, a different ratio of amino acids, minerals and other new additives such as prebiotics and probiotics to enhance digestive enzymes and immune responses.

\section{Acknowledgements}

The authors thank Deanship of Scientific Research at King Saud University for the funding of this research through the Research Group Project No. RGP-VPP-304.

\section{References}

ABDEL-WARITH, A.A., RUSSELL, P.M., and DAVIES, S.J., 2001. Inclusion of a commercial poultry by-product meal as a protein replacement of fishmeal in practical diets for African catfish, 
Clarias gariepinus. Aquaculture Research, vol. 32, suppl. 1, pp. 296-305. http://dx.doi.org/10.1046/j.1355-557x.2001.00053.x.

ABDEL-WARITH, A.A., YOUNIS, E.M., AL-ASGAH, N.A. and ALLAM, H.Y., 2014. Maize gluten meal as a protein source in diets for African catfish Clarias gariepinus, including effects on liver glycogen and histology. Indian Journal of Fisheries, vol. 61 , no. 3 , pp. $74-82$.

ABDEL-WARITH, A.-W.A., YOUNIS, E.M. and ABDUALLA, A.-A.N., 2013. Influence of dietary inclusion of full-fat soybean meal and amino acids supplementation on growth and digestive enzymes activity of Nile Tilapia, Oreochromis niloticus. Turkish Journal of Fisheries and Aquatic Sciences, vol. 13, no. 1, pp. 6977. http://dx.doi.org/10.4194/1303-2712-v13_1_09.

ALARCON, F.J., GARCIA-CARRENO, F.L. and NAVARRETE DEL TORO, M.A., 2001. Effect of plant protease inhibitors on digestive proteases in two fish species, Lutjanus argentiventris and L. novemfasciatus. Fish Physiology and Biochemistry, vol. 24, no. 3, pp. 179-189. http://dx.doi.org/10.1023/A:1014079919461.

ALEGBELEYE, W.O., OBASA, S.O., OLUDE, O.O., OTUBU, K. and JIMOH, W., 2012. Preliminary evaluation of the nutritive value of the variegated grasshopper, (Zonocerus variegatus $\mathrm{L}$.) for African catfish, Clarias gariepinus (Burchell. 1822) fingerlings. Aquaculture Research, vol. 43, no. 3, pp. 412-420. http://dx.doi. org/10.1111/j.1365-2109.2011.02844.x.

AL-OWAFEIR, M., 1999. The effect of dietary saponin and tannin on growth performance and digestion in $O$. niloticus and Clarias gariepinus. Stirling: Institute of Aquaculture, University of Stirling, $220 \mathrm{p}$. PhD thesis.

ASSOCIATION OF OFFICIAL ANALYTICAL CHEMISTS AOAC, 1995. Official methods of analysis. 15th ed. Washington: AOAC, 1094 p.

DAS, H.M. and TRIPATHI, S.D., 1991. Studies on digestive enzymes of grass carp (Ctenopharyngodon idella Val.). Aquaculture (Amsterdam, Netherlands), vol. 92, pp. 21-32. http://dx.doi. org/10.1016/0044-8486(91)90005-R.

DAVIES, S.J., ABDEL-WARITH, A.A. and GOUVEIA, A., 2011. Digestibility characteristics of selected feed ingredients for developing bespoke diets for Nile tilapia culture in Europe and North America. Journal of the World Aquaculture Society, vol. 42, no. 3, pp. 388-398. http://dx.doi.org/10.1111/j.17497345.2011.00478.x

EL-BELTAGY, A.E., EL-ADAWY, T.A., RAHMA, E.H. and EL-BEDAWEY, A.A., 2004. Purification and characterization of an acidic protease from the viscera of bolti fish (Tilapia nilotica). Food Chemistry, vol. 86, no. 1, pp. 33-39. http://dx.doi. org/10.1016/j.foodchem.2003.08.009

ERLANGER, B., KOKOWSKY, N. and COHEN, W., 1961. The preparation and properties of two new chromogenic substrates of trypsin. Archives of Biochemistry and Biophysics, vol. 95, no. 2, pp. 271-278. http://dx.doi.org/10.1016/0003-9861(61)90145-X. PMid:13890599.

FAGBENRO, O.A. and DAVIES, S.J., 2001. Use of soybean flour (dehulled solvent extracted soybean) as fishmeal substitute in practical diet for African catfish, Clarias gariepinus (Burchell 1822) growth, feed utilization and digestibility. Journal of Applied Ichthyology, vol. 17, no. 2, pp. 64-69. http://dx.doi. org/10.1046/j.1439-0426.2001.00252.x.

FRANCIS, G., MAKKAR, H.P.S. and BECKER, K., 2001. Antinutritional factors present in plant-derived alternate fish feed ingredients and their effects in fish. Aquaculture (Amsterdam, Netherlands), vol. 199, no. 3-4, pp. 197-227. http://dx.doi. org/10.1016/S0044-8486(01)00526-9.

GARCÍA, V., CELADA, J.D., GONZÁLEZ, R., CARRAL, J.M., SÁEZ-ROYUELA, M. and GONZÁLEZ, Á., 2015. Response of juvenile tench (Tinca tinca $L$.) fed practical diets with different protein contents and substitution levels of fish meal by soybean meal. Aquaculture Research, vol. 46, no. 1, pp. 28-38. http://dx.doi.org/10.1111/are.12154.

GODA, A.M., WAFA, M.E., EL-HAROUN, E.R. and KABIR CHOWDHURY, M.A., 2007. Growth performance and feed utilization of Nile tilapia Oreochromis niloticus (Linnaeus, 1758) and tilapia galilee, Sarotherodon galilaeus (Linnaeus, 1758) fingerlings fed plant protein-based diets. Aquaculture Research, vol. 38, no. 8, pp. 827-837. http://dx.doi.org/10.1111/j.13652109.2007.01731.x

HARLIOĞLU, A.G., 2011. The influence of replacing fish meal partially in diet with soybean meal and full-fat soya on growth and body composition of rainbow trout (Oncorhynchus mykiss). Pakistan Journal of Zoology, vol. 43, no. 1, pp. 175-182.

HENDRICKS, J.D., 2002. Adventitious toxins. In: J.E. HALVER and R.W. HARDY, eds. Fish nutrition. 3rd ed, London: Academic Press, pp. 143-159.

HEPHER, B., LIAO, V., CHENG, S.H. and HSIEH, C.S., 1983. Food utilization by red tilapia, effect of diet composition, feeding level and temperature on utilization efficiencies for maintenance and growth. Aquaculture (Amsterdam, Netherlands), vol. 32, no. 3-4, pp. 255-275. http://dx.doi.org/10.1016/0044-8486(83)90223-5.

HIDALGO, M.C., UREA, E. and SANZ, A., 1999. Comparative study of digestive enzymes in fish with different nutritional habits. Proteolytic and amylase activities. Aquaculture (Amsterdam, Netherlands), vol. 170, no. 3-4, pp. 267-283. http://dx.doi. org/10.1016/S0044-8486(98)00413-X.

HUISMAN, E.A. and RICHTER, C.J.J., 1987. Reproduction, growth, health control and aquaculture potential of the African catfish, Clarias gariepinus (Burchell 1822). Aquaculture (Amsterdam, Netherlands), vol. 63, no. 1-4, pp. 1-14. http:// dx.doi.org/10.1016/0044-8486(87)90057-3.

IMOROU TOKO, I., FIOGBE, D.E. and KESTEMONT, P., 2008. Mineral status of African catfish (Clarias gariepinus) fed diets containing graded levels of soybean or cottonseed meals. Aquaculture (Amsterdam, Netherlands), vol. 275, no. 1-4, pp. 298-305. http://dx.doi.org/10.1016/j.aquaculture.2007.11.038.

KOKOU, F., RIGOS, G., HENRY, M., KENTOURI, M. and ALEXIS, M., 2012. Growth performance, feed utilization and non-specific immune response of gilthead sea bream (Sparus aurata L.) fed graded levels of a bioprocessed soybean meal. Aquaculture (Amsterdam, Netherlands), vol. 364-365, pp. 74-81. http://dx.doi.org/10.1016/j.aquaculture.2012.08.009.

KUNITZ, M., 1947. Crystalline soybean trypsin inhibitor: II. General properties. The Journal of General Physiology, vol. 30, no. 4, pp. 291-310. http://dx.doi.org/10.1085/jgp.30.4.291. PMid:19873496.

LOVATTO, N.D.M., GOULART, F.R., LOUREIRO, B.B., ADORIAN, T.J., DE FREITAS, S.T., PIANESSO, D., DALCIN, M.O., ATHAYDE, M.L. and SILVA, L.P., 2017. Effects of phosphorylated protein concentrate of pumpkin seed meal on growth and digestive enzymes activity of silver catfish, Rhamdia quelen. Aquaculture Nutrition, vol. 23, no. 1, pp. 201-209. http:// dx.doi.org/10.1111/anu.12381. 
LUO, L., XUE, M., WU, X., CAI, X., CAO, H. and LIANG, Y., 2006. Partial or total replacement of fishmeal by solvent-extracted cottonseed meal in diets for juvenile rainbow trout, (Oncorhynchus mykiss). Aquaculture Nutrition, vol. 12, no. 6, pp. 418-424. http:// dx.doi.org/10.1111/j.1365-2095.2006.00443.x.

MCCULLAGH, J.S.O., JUCHELKA, D. and HEDGES, R.E.M., 2006. Analysis of amino acid $13 \mathrm{C}$ abundance from human and faunal bone collagen using liquid chromatography/ isotope ratio mass spectrometry. Rapid Communications in Mass Spectrometry, vol. 20, no. 18, pp. 2761-2768. http://dx.doi.org/10.1002/rcm.2651. PMid:16921562

MELO, J.F.B., LUNDSTEDT, L.M., MORAES, G. and INOUE, L.A.K.A., 2012. Effect of different concentrations of protein on the digestive system of juvenile silver catfish. Arquivo Brasileiro de Medicina Veterinária e Zootecnia, vol. 64, no. 2, pp. 450-457. http://dx.doi.org/10.1590/S0102-09352012000200027.

NUTRIENT REQUIREMENTS OF FISH - NRC, 1993. Nutrient requirements of fish. Washington: National Academy Press. p: 114.

NWANNA, L., BALOGUN, A.M., AJENIFUJA, Y.F. and ENUJIUGHA, V.N., 2004. Replacement of fish meal with chemically preserved shrimp head in the diets of African catfish, (Clarias gariepinus). Journal of Food Agriculture and Environment, vol. 2 , no. 1 , pp. $79-83$.

OLALEYE, I.G., 2015. Effects of grasshopper meal in the diet of Clarias gariepinus fingerlings. Journal of Aquaculture Research \& Development, vol. 6, no. 4, pp. 321.

PENN, M.H., BENDIKSEN, E.A., CAMPBELL, P. and KROGDAHL, A., 2011. High level of dietary pea protein concentrate induces enteropathy in Atlantic salmon (Salmo salar L.). Aquaculture (Amsterdam, Netherlands), vol. 310, no. 3-4, pp. 267-273. http://dx.doi.org/10.1016/j.aquaculture.2010.10.040.

SANTIGOSA, E., SÁNCHEZ, J., MÉDALE, F., KAUSHIK, S., PÉREZ-SÁNCHEZ, J. and GALLARDO, M.A., 2008. Modifications of digestive enzymes in trout, (Oncorhynchus mykiss) and sea bream, (Sparus aurata) in response to dietary fish meal replacement by plant protein sources. Aquaculture (Amsterdam, Netherlands), vol. 282, no. 1-4, pp. 68-74. http:// dx.doi.org/10.1016/j.aquaculture.2008.06.007.

SHIAU, S.Y., LIN, S.F., YU, S.L., LIN, A.L. and KWOK, C.C., 1990. Defatted and full-fat soybean meal as partial replacements for fishmeal in tilapia (Oreochromis niloticus $\times$ O. aureus) diets at low protein level. Aquaculture (Amsterdam, Netherlands), vol. 86, no. 4, pp. 401-407. http://dx.doi.org/10.1016/00448486(90)90328-K.

SHIMENO, S., MIMA, T., IMANAGA, T. and TOMARU, K., 1993. Inclusion of combination of defatted soybean meal, meat meal and corn gluten meal to yellowtail diet. Nippon Suisan Gakkaishi, vol. 59, no. 11, pp. 1889-1895. http://dx.doi. $\operatorname{org} / 10.2331 /$ suisan.59.1889.

SNEDECOR, G.W. and COCHRAN, W.G., 1989. Statistical methods. Ames: The Iowa State University Press, 476 p.

SONG, Z.D., LI, H.Y., WANG, J.Y., LI, P.Y., SUN, Y.Z. and ZHANG, L.M., 2014. Effects of fish meal replacement with soy protein hydrolysates on growth performance, blood biochemistry, gastrointestinal digestion and muscle composition of juvenile starry flounder (Platichthys stellatus). Aquaculture (Amsterdam, Netherlands), vol. 426-427, pp. 96-104. http://dx.doi.org/10.1016/j. aquaculture.2014.01.002.

SRIKET, C., BENJAKUL, S., VISESSANGUAN, W. and HARA, K., 2011. Effect of legume seed extracts on the inhibition of proteolytic activity and muscle degradation of fresh water prawn Macrobrachium rosenbergii. Food Chemistry, vol. 129, no. 3, pp. 1093-1099. http://dx.doi.org/10.1016/j.foodchem.2011.05.080. PMid:25212342.

SUN, H., TANG, J.W., YAO, X.H., WU, Y.F., WANG, X., LIU, Y. and LOU, B., 2015. Partial substitution of fish meal with fermented cottonseed meal in juvenile black sea bream (Acanthopagrus schlegelii) diets. Aquaculture (Amsterdam, Netherlands), vol. 446, pp. 30-36. http://dx.doi.org/10.1016/j. aquaculture.2015.04.020.

TENGJAROENKUL, B., SMITH, B.J., CACECI, T. and SMITH, S.A., 2000. Distribution of intestinal enzyme activities along the intestinal tract of cultured Nile tilapia O.niloticus L. Aquaculture (Amsterdam, Netherlands), vol. 182, no. 3-4, pp. 317-327. http:// dx.doi.org/10.1016/S0044-8486(99)00270-7.

TIETZ, N., 1970. Fundamentals of clinical chemistry. Philadelphis: W.B. Saunders Press, 983 pp.

WALTER, H.E., 1984. Proteinases: methods with hemoglobin, casein and azocoll as substrates. In: H.U. BERGMEYER, ed. Methods of enzymatic analysis. Weinheim: Verlag Chemie, pp. 270-277.

XIONG, D.M., XIE, C.X., ZHANG, H.J. and LIU, H.P., 2011. Digestive enzymes along digestive tract of a carnivorous fish Glyptosternum maculatum (Sisoridae, Siluriformes). Journal of Animal Physiology and Animal Nutrition, vol. 95, no. 1, pp. 56-64. http://dx.doi.org/10.1111/j.1439-0396.2009.00984.x. PMid:20487102.

XU, Q.Y., WANG, C.A., ZHAO, Z.G. and LUO, L., 2012. Effects of replacement of fish meal by soy protein isolate on the growth, digestive enzyme activity and serum biochemical parameters for juvenile Amur sturgeon (Acipenser schrenckii). Asian-Australasian Journal of Animal Sciences, vol. 25, no. 11, pp. 1588-1594. http:// dx.doi.org/10.5713/ajas.2012.12192. PMid:25049521.

ZAID, A.A. and GANIYAT, O., 2009. Comparative utilization of biodegraded and undegraded rice husk in Clarias gariepinus diet. African Journal of Biotechnology, vol. 8, no. 7, pp. 1358-1362.

ZHANG, Y.Q., WU, Y.B., JIANG, D.L., QIN, J.G. and WANG, Y., 2014. Gamma-irradiated soybean meal replaced more fish meal in the diets of Japanese seabass (Lateolabrax japonicus). Animal Feed Science and Technology, vol. 197, pp. 155-163. http://dx.doi.org/10.1016/j.anifeedsci.2014.08.002.

ZHAO, Z., SONG, C., XIE, J., GE, X., LIU, B., XIA, S., YANG, S., WANG, Q. and ZHU, S., 2016. Effects of fish meal replacement by soybean peptide on growth performance, digestive enzyme activities, and immune responses of yellow catfish Pelteobagrus fulvidraco. Fisheries Science, vol. 82, no. 4, pp. 665-673. http:// dx.doi.org/10.1007/s12562-016-0996-6. 